\title{
Phytoplankton growth rates in a light-limited environment, San Francisco Bay
}

\author{
Andrea E. Alpine, James E. Cloern \\ US Geological Survey MS496, 345 Middlefield Road, Menlo Park, California 94025, USA
}

\begin{abstract}
San Francisco Bay has a high degree of spatial variability in physical properties (e.g. suspended sediment concentrations, water depths, vertical mixing rates) that affect biological processes. We used this setting to test the hypothesis that light availability is the primary control of phytoplankton growth in this turbid nutrient-rich estuary. In situ incubations $(24 \mathrm{~h})$, designed to simulate vertical mixing over the water column at 2 rates, were done at 4 sites. The photic depth to mixed depth ratio $\left(Z_{\mathrm{p}}: Z_{\mathrm{m}}\right)$ at the 4 sites ranged from 0.12 to 1.1. Phytoplankton growth rates were estimated by ${ }^{14} \mathrm{C}$ assimilation and by changes in cell number. Growth rates were highest (approximately 2 divisions $d^{-1}$ ) where the photic depth was large relative to the mixed depth, and small or negative where $Z_{\mathrm{p}}: Z_{\mathrm{m}}$ was small. Growth rate increased with total daily light exposure and fit a hyperbolic function that predicts maximum specific growth rate of about 2 divisions $d^{-1}$ and a compensation irradiance of about 1.4 Einst. $\mathrm{m}^{-2} \mathrm{~d}^{-1}$.
\end{abstract}

\section{INTRODUCTION}

Phytoplankton cells reside in a turbulent medium partitioned into an upper photic zone that sustains photosynthesis, and a lower aphotic zone that does not. In estuaries, vertical mixing rates between these 2 zones can be rapid $(<1$ generation time) because of tidal stirring and because the mixing depth is generally shallow. Moreover, the photic depth is characteristically shallow in estuaries because of the high seston concentrations that typify these systems (e.g. Cloern 1987). Hence the mean light exposure of phytoplankton cells, and their rates of photosynthesis and growth in estuaries, should be related to the ratio of photic depth $Z_{\mathrm{p}}$ to mixing $Z_{\mathrm{m}}$ (defined as either the water column depth, or the surface layer depth in a stratified estuary).

Grobbelar (1985) has measured phytoplankton production in turbid waters and used the ratio $Z_{\mathrm{p}}: Z_{\mathrm{m}}$ as a simple index to quantify the degree of light limitation. Harris and his colleagues have examined in detail the importance of the $Z_{\mathrm{p}}: Z_{\mathrm{m}}$ ratio in lakes for influencing variability of phytoplankton production and photosynthetic parameters (Harris et al. 1980), and variability of species composition both temporally (Harris \& Piccinin 1980) and spatially (Haffner et al. 1980). Phytoplankton growth rates have only rarely been measured in estuaries (Malone 1977, Furnas 1982, Harding et al. 1986) where cycling rates between the photic and aphotic zones can be much faster than in laknes or the open ocean.

This study was motivated by the need for quantitative measures of phytoplankton population growth rate in an estuarine environment, and was designed around the presumption that growth rates can be related empirically to light exposure. We conducted the study in San Francisco Bay (California, USA), which has large horizontal gradients in light availability $\left(Z_{\mathrm{p}}: Z_{\mathrm{m}}\right)$ typical of many coastal plain estuaries, and nutrient concentrations that often exceed those presumed to limit phytoplankton growth (Cloern et al. 1985). We tested the hypothesis that light availability is the primary control of phytoplankton growth, and that previous estimates of growth rate based on the ratio of productivity to biomass (Cloern et al. 1985) are realistic. Specifically, we wanted to verify that growth rate varies spatially along horizontal gradients of light availability indexed as $Z_{\mathrm{p}}: Z_{\mathrm{m}}$, such that phytoplankton turnover rate is rapid in shallow clear areas (high $Z_{\mathrm{p}}: Z_{\mathrm{m}}$ ) and slow in deep turbid areas (low $Z_{\mathrm{p}}: Z_{\mathrm{m}}$ ). We used an in situ incubation technique which simulated vertical mixing, and measured both changes in cell number and carbon production as independent estimates of growth rate across a range of $Z_{\mathrm{p}}: Z_{\mathrm{m}}$ ratios. 


\section{METHODS}

Experimental design. San Francisco Bay has a central deep $(10$ to $30 \mathrm{~m})$ channel flanked by a broad expanse of subtidal shoals $(<3 \mathrm{~m}$ depth). It also has a wide range of SPM (suspended particulate matter) concentrations reflected in contours of the light extinction coefficient $k$ (e.g. Fig. 1). To examine growth rates over a range of light environments (i.e. $Z_{\mathrm{p}}: Z_{\mathrm{m}}$ ratios), 4 experimental sites (Fig. 1) were chosen: 2 channel sites (depth $10 \mathrm{~m}$ ), one each in the extremely turbid North Bay and the less turbid South Bay; and 2 shoal sites (depth $2 \mathrm{~m}$ ), one from each bay. Four $Z_{\mathrm{p}}: Z_{\mathrm{m}}$ ratios were used in these experiments (Fig. 2), based upon measured mean $k$ at each site during 1980 (Cloern et al. 1985). Although the deep channel of San Francisco Bay can be density stratified, particularly during the winterspring period of high river discharge, the upper estuary and South Bay are well mixed or only weakly stratified during the dry summer-autumn (Walters et al. 1985). Our experiments were designed to simulate conditions

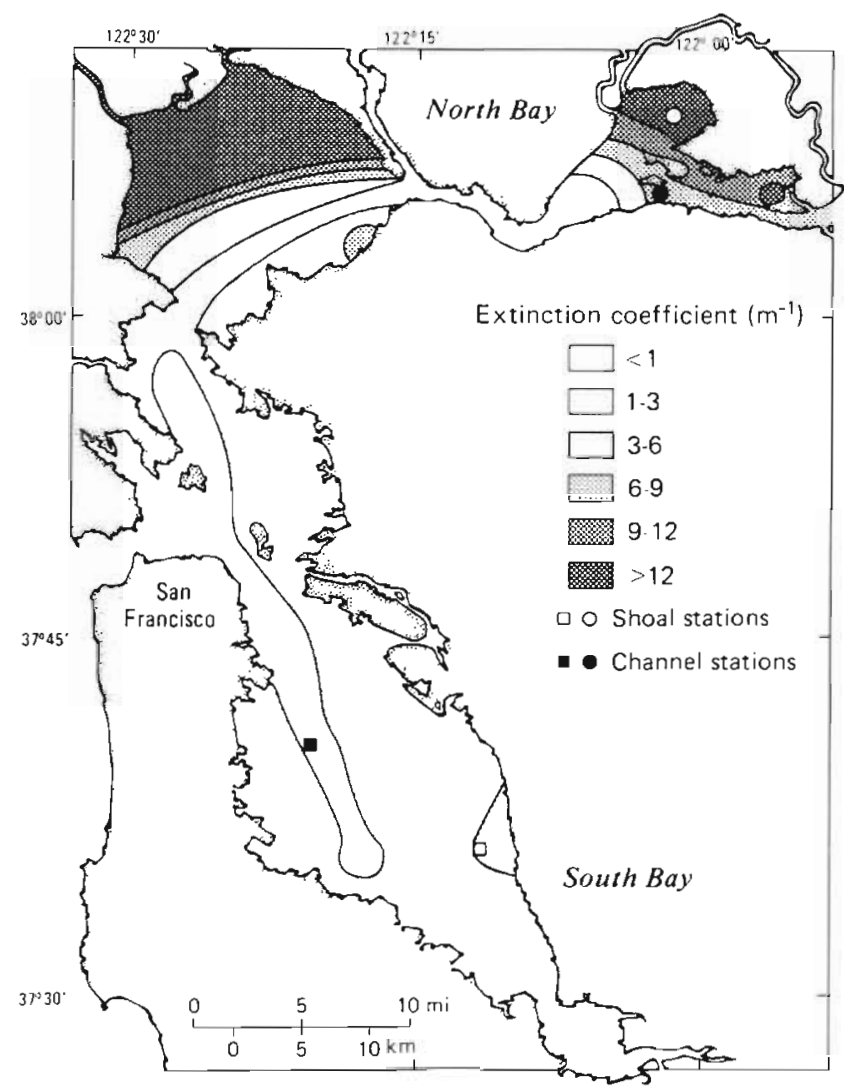

Fig. 1. Contours of the light extinction coefficient measured in San Francisco Bay during August 1980, representative of the summer-fall season. Turbidity measurements were made at 94 sites throughout the estuary with a nephelometer These measurements were calibrated against extinction coefficients obtained with a LiCor $192 \mathrm{~S}$ quantum sensor. Also shown are

the 4 sampling sites for the experiments described here

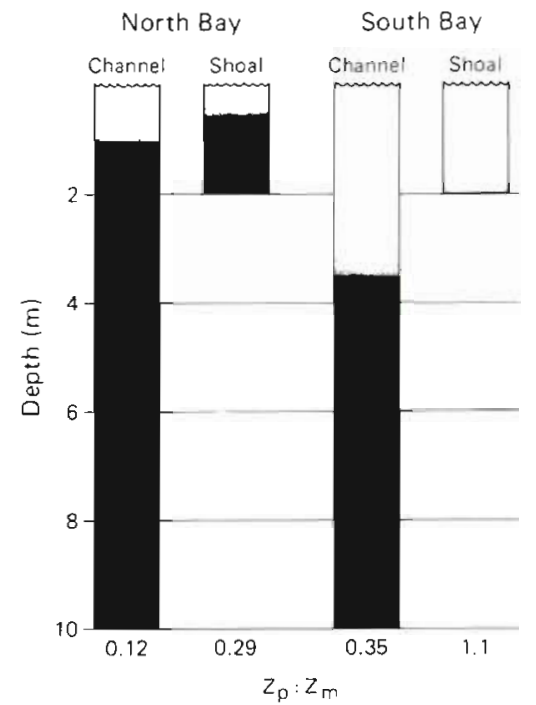

Fig. 2. Photic depth to mixed depth ratio $\left(Z_{\mathrm{p}}: Z_{\mathrm{m} 1}\right)$ at the 4 experimental sites

of a well-mixed estuary (i.e. $Z_{\mathrm{m}}=$ water depth). These experiments were done in September to represent the summer-autumn period when growth rates are presumably maximal in San Francisco Bay (Cloern et al. 1985), and when freshwater inflow and stratification are minimal.

Growth rates were measured by incubating samples in situ and simulating high frequency variations in light exposure that phytoplankton cells mixed throughout a turbulent water column might experience. Our incubation technique was not designed to measure changes in photoadaptive parameters as a function of mixing speed (e.g. Lewis et al. 1984), but rather was a technique to simulate transport of phytoplankton between the photic and aphotic zones so that dark processes (respiration) would be included in the growth estimates. This approach differed from previous studies (e.g. Jewson \& Wood 1975, Marra 1978, Gallegos \& Platt 1982) which simulated mixing within the photic zone only. Preliminary numerical experiments from computer models indicated that results of such measurements can be sensitive to vertical mixing rates (i.e. nature of light exposure during incubations), so we chose 2 mixing rates that correspond to the range in vertical eddy diffusivities over the neap-spring tidal cycle. These vertical speeds were calculated as depth $Z_{\mathrm{Th}}$ divided by the estimated time scale for vertical mixing in a homogenous water column (Walters et al. 1985). Because the eddy diffusivity scales with tidal current speed, and hence water depth (Walters et al. 1985), a different range of mixing speeds was specified for the channel ( 1.0 and $5.0 \mathrm{~m} \mathrm{~h}^{-1}$ ) and shoal sites $(0.5$ and $1.5 \mathrm{~m} \mathrm{~h}^{-1}$ ). Although these estimates of vertical mixing rate are crude approximations, they are within 
the range calculated by Denman \& Gargett (1983) for turbulent mixing in the upper ocean. It should be noted, however, that these mixing speeds are considerably slower than other researchers have used to simulate organized motions such as those of Langmuir circulation cells (e.g. Marra 1978, Yoder \& Bishop 1985).

The incubation experiments were designed to simulate high frequency variations in light exposure due to vertical motions as well as diurnal changes in surface irradiance, for mean summer-autumn conditions in San Francisco Bay. To do this, we incubated water samples in situ and moved the incubation bottles vertically during the course of the experiment according to a prescribed schedule using the following equation (Parsons et al. 1977):

$$
I_{t}=I_{\max }\left[\sin ^{3}(\pi / D) t_{i}\right] \mathrm{e}^{-k z}
$$

where $I_{t}=$ prescribed irradiance at time $t(\mathrm{~h})_{i} I_{\max }=$ surface irradiance at solar noon $\left(=2000 \mu\right.$ Einst. $\mathrm{m}^{-2}$ $\left.\mathrm{s}^{-1}\right) ; D=$ photoperiod $(=13 \mathrm{~h})$; and $k=$ mean extinction coefficient specific to each site. In calculating these schedules of light exposure, the depth variable $z(\mathrm{~m})$ was changed every 15 min based on an initial starting position in the water column and an incremental displacement using the prescribed vertical mixing rate. These schedules defined circular trajectories of movement in the water column and included no random component of vertical motion. It is important to note that these experiments were designed to measure potential maximum growth rates, not mean in situ rates. This was done by using that mixing schedule which maximized daily light exposure (typically this meant that incubation bottles were near the surface at solar noon).

Previous estimates of growth rates in San Francisco Bay have been based on carbon production normalized to biomass (Cloern et al. 1985). Other researchers have shown that carbon production and cell division may not be tightly coupled (Pruder \& Bolton 1980, Cosper 1982, Reynolds et al. 1985), so we measured both change in cell number and carbon productivity as independent estimates of growth rate.

Experimental procedure. From each site, surface water samples were collected with buckets and screened through $60 \mu \mathrm{m}$ mesh to remove macrozooplankton. Polycarbonate bottles of 4 l capacity were filled and incubated in situ for $24 \mathrm{~h}$ beginning at dawn. Vertical mixing was simulated by manually moving the bottles every $15 \mathrm{~min}$ according to the schedule prescribed for each experiment, using irradiance measurements with LiCor quantum sensors (192S) attached to each incubation rack. Instantaneous irradiance was recorded every $15 \mathrm{~min}$ and integrated over the day to obtain total irradiance $I$.

Carbon production was determined using the ${ }^{14} \mathrm{C}$ acid bubbling technique (Schindler et al. 1972). Following incubation, aliquots $(3 \mathrm{ml})$ from each bottle were placed in scintillation vials. Unincorporated ${ }^{14} \mathrm{C}$ was stripped from the sample and the residual activity measured with a scintillation counter, Duplicate chlorophyll samples were taken at each site, also prescreened with $60 \mu \mathrm{m}$ mesh. Chlorophyll a, corrected for pheopigments, was determined spectrophotometrically (Lorenzen 1967, Riemann 1978).

Samples for phytoplankton identification and enumeration were preserved with Lugol's solution. Aliquots $(150 \mathrm{ml})$ were collected from each initial sample, each incubated bottle, and a 'dark' bottle (incubated at in situ temperatures and kept in total darkness). At least 300 algal cells were enumerated both at $1000 \times$ and $80 \times$ using an inverted microscope. The historical estimate of precision (i.e. average coefficient of variation for triplicate counts) is $8 \%$ (Wong \& Cloern 1982).

Growth rates (divisions $\mathrm{d}^{-1}$ ) based on cell division $\left(\mu_{1}\right)$ and based on carbon production $\left(\mu_{2}\right)$ were calculated as follows:

$$
\mu_{1}=\log _{2}\left[N_{\mathrm{f}} / N_{\mathrm{d}}\right]
$$

where $N_{\mathrm{f}}=$ mean cell density after in situ incubation; and $N_{\mathrm{d}}=$ mean cell density after dark incubation (to correct for cell divisions unrelated to light exposure);

$$
\mu_{2}=\log _{2}\left\{\left[C_{1}+\left(C_{p}-C_{d}\right)\right] / C_{i}\right.
$$

where $C_{p}=$ production $\left(\mathrm{mg} \mathrm{C} \mathrm{m}^{-3}\right.$ ) during in situ incubation; $C_{d}=$ carbon assimilation in the dark; and $C_{i}=$ initial phytoplankton biomass as carbon $\left(\mathrm{mg} \mathrm{m}^{-3}\right)$. Phytoplankton biomass was calculated as the product of the initial chlorophyll a concentration and an estimated mean carbon to chlorophyll a ratio of 50 (Wienke \& Cloern 1987).

\section{RESULTS}

The initial conditions for each experiment are shown in Table 1. Salinity was about 3 in the North Bay and 30

\begin{tabular}{|c|c|c|c|c|}
\hline & $\begin{array}{r}\text { North } \\
\text { Channel }\end{array}$ & $\begin{array}{l}\text { Bay } \\
\text { Shoal }\end{array}$ & $\begin{array}{r}\text { South } \\
\text { Channel }\end{array}$ & $\begin{array}{l}\text { Bay } \\
1 \text { Shoal }\end{array}$ \\
\hline Salinity & 3.5 & 2.4 & 30.3 & 31.1 \\
\hline Temperature $\left({ }^{\circ} \mathrm{C}\right)$ & 22.2 & - & 22.0 & - \\
\hline Chlorophyll a $\left(\mu \mathrm{g} \mathrm{l}^{-1}\right)$ & 13.9 & 18.4 & 2.3 & 1.9 \\
\hline $\operatorname{DIN}^{a}\left(\mu g-a t 1^{-1}\right)$ & 5.46 & 0.43 & 21.56 & 1.56 \\
\hline $\mathrm{PO}_{4}\left(\mu \mathrm{g}-\mathrm{at} \mathrm{l}^{-1}\right)$ & 1.90 & 1.67 & 11.70 & 9.30 \\
\hline $\mathrm{SiO}_{3}($ ug-at l-1) & 130 & 130 & 111 & 105 \\
\hline
\end{tabular}
in the South Bay; water temperature was $22^{\circ} \mathrm{C}$ in both

Table 1. Initial experimental conditions 
embayments. Chlorophyll a concentrations ranged from $1.9 \mu \mathrm{g} \mathrm{I}^{-1}$ at the South Bay shoal site to $18.4 \mu \mathrm{g} \mathrm{I}^{-1}$ at the North Bay shoal site. Concentrations of dissolved inorganic nutrients ( $N, P, S i)$ at the channel locations exceeded those presumed to limit phytoplankton growth. However dissolved inorganic nitrogen concentration was low $\left(<0.5 \mu \mathrm{g}\right.$-at $\mathrm{I}^{-1}$ ) at the North Bay shoal site (Table 1). As observed historically, diatoms and small cryptophytes were the dominant phytoplankton throughout the estuary.

Fig. 3 details the light exposure of each incubation
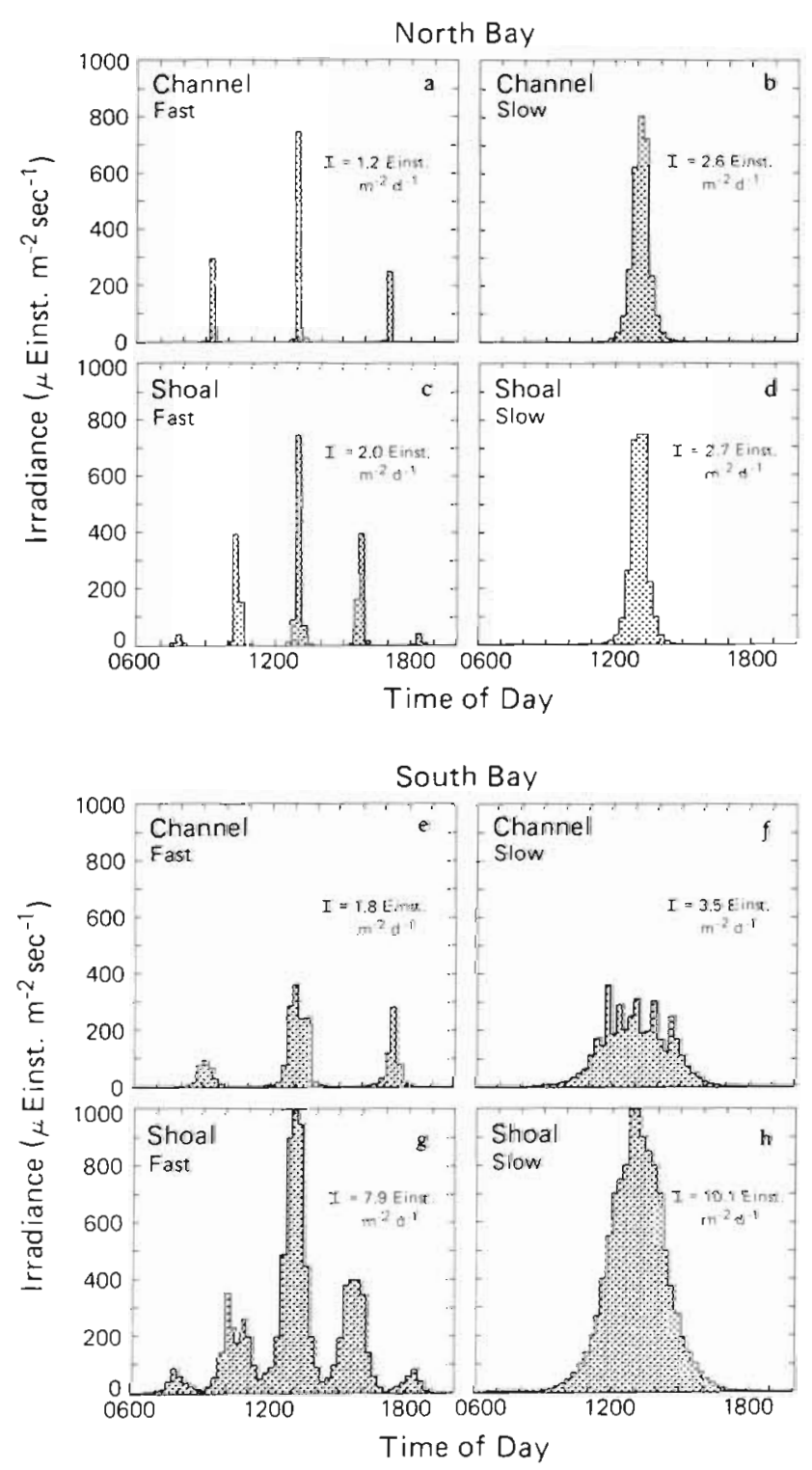

Fig. 3. Light exposure of each incubation bottle during the course of vertical mixing experiments (Irradiance $=I_{t}$ ). Left panels (a, c, e, g) represent high frequency (fast vertical mixing rate) light exposure; right panels $(b, d, f, h)$ represent the light exposure from vertical mixing at the slowest rates. Also shown is total daily irradiance (l) for each incubation bottle bottle during the course of the $24 \mathrm{~h}$ experiments. Both the amount of light received and the timing of the exposure varied with $Z_{\mathrm{m}}$ (i.e. between channel and shoal sites), with $Z_{\mathrm{p}}$ (i.e. between embayments), and with mixing rate. In general, light exposure with the slow mixing rates was characterized by one broad peak centered around solar noon, reflecting the diurnal cycle (e.g. Figs. 3d, h). At the other extreme, rapid vertical mixing generated more variable light exposures such that the incubation bottles were moved between the photic and aphotic zone repeatedly over the photoperiod (e.g. Fig. 3c, g). Total irradiance ranged from 1.2 to 10.1 Einst. $\mathrm{m}^{-2} \mathrm{~d}^{-1}$, which encompasses the range in average water column light intensities found in this estuary (Cloern et al. 1985).

Table 2. Phytoplankton growth rates based on cell division $\left(\mu_{1}\right)$ and biomass-normalized carbon production $\left(\mu_{2}\right)$ using 2 mixing rates at 4 sites within San Francisco Bay. I: total irradiance (PAR) for each mixing rate. Fast mixing rate $(F)=5 \mathrm{~m} \mathrm{~h}^{-1}$ (channel) or $1.5 \mathrm{~m} \mathrm{~h}^{-1}$ (shoal). Slow mixing rate $(\mathrm{S})=1 \mathrm{~m} \mathrm{~h}^{-1}$ (channel) or $0.5 \mathrm{~m} \mathrm{~h}^{-1}$ (shoal)

\begin{tabular}{|c|c|c|c|c|c|c|c|}
\hline & \multicolumn{4}{|c|}{ North Bay } & \multicolumn{3}{|c|}{ South Bay } \\
\hline & \multicolumn{2}{|c|}{ Channel } & \multicolumn{2}{|c|}{ Shoal } & \multicolumn{2}{|c|}{ Channel } & Shoal \\
\hline & $\mathrm{F}$ & s & $\mathrm{F}$ & $S$ & $\mathrm{~F}$ & $\mathrm{~S}$ & $\mathrm{~S}$ \\
\hline$\mu_{1}\left(\right.$ div. $\left.\mathrm{d}^{-1}\right)$ & -0.1 & 0.5 & 0.4 & 0.2 & 0.8 & 1.2 & $1.9 \quad 1.8$ \\
\hline$\mu_{2}\left(\right.$ div $\left.\mathrm{d}^{-1}\right)$ & 0.2 & 0.3 & 0.2 & 0.3 & 0.6 & 1.1 & $1.7 \quad 1.3$ \\
\hline$I$ (Einst. $\left.\mathrm{m}^{-2} \mathrm{~d}^{-1}\right)$ & 1.2 & 2.6 & 2.0 & 2.7 & 1.8 & 3.5 & 7.910 .1 \\
\hline
\end{tabular}

Phytoplankton growth rates differed among the 4 locations, ranging from -0.10 to 1.9 divisions $\mathrm{d}^{-1}$ based on cell counts and 0.17 to 1.7 divisions $\mathrm{d}^{-1}$ based on carbon production (Table 2). The spatial variation in growth rates tracked the variation in the $Z_{\mathrm{p}}: Z_{\mathrm{m}}$ ratio. The fastest growth rates were found in the shoals of the South Bay where $Z_{\mathrm{p}}: Z_{\mathrm{m}}>1$, and the slowest growth rates were measured in the channel of the North Bay where $Z_{\mathrm{p}}: Z_{\mathrm{m}}=0.12$. Because the mixing schedules optimized light exposure to each incubation bottle, these measured growth rates represent upper limits rather than mean growth rates for the given mixing rates and $Z_{\mathrm{p}}: Z_{\mathrm{m}}$ ratios.

In these experiments we used 2 methods to measure phytoplankton growth: one based on cell division and one based on biomass-normalized carbon assimilation. These 2 methods yielded growth rates of similar magnitude (Fig. 4), and the 2 measures were highly correlated $\left(r^{2}=0.93\right)$. The regression slope (Eq. 4) indicates that cell division was faster $(1.3 \times)$ than the calculated turnover rate of phytoplankton carbon measured by ${ }^{14} \mathrm{C}$ uptake:

$$
\mu_{2}=0.04+0.76 \mu_{1}
$$

Asynchrony between cell division and photosynthesis has been demonstrated in the laboratory with culture 


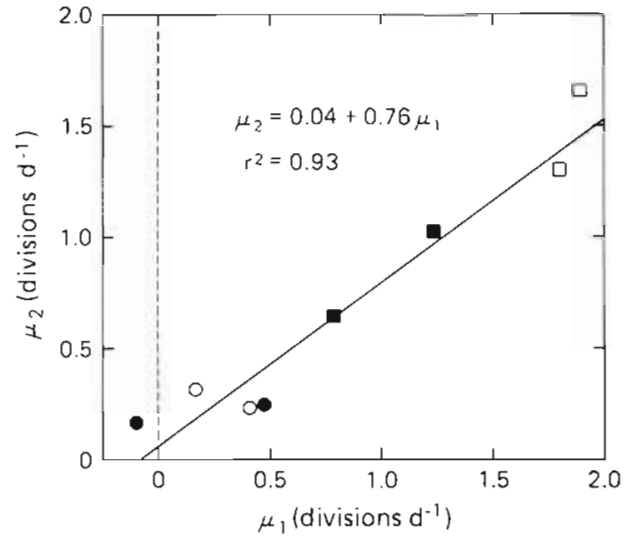

Fig. 4. Regression of $\mu_{2}$ (growth rate based on carbon production normalized to biomass) against $\mu_{1}$ (growth rate based on changes in cell numbers). Symbols represent the stations as in Fig. 1

experiments (e.g. Pruder \& Bolton 1980, Langdon 1987). However generalities about cell division occurring more rapidly than carbon production, from field studies such as this, should be made with caution, Estimates of $\mu_{2}$ (from productivity) are based on an assumed ratio of phytoplankton carbon:chlorophyll $a$ which was specified here as 50. However the 2 methods would yield identical mean growth rates (regression slope of 1) given a carbon:chlorophyll a ratio of 38 , which is within the range expected for natural phytoplankton populations (e.g. Malone 1977. Cullen 1982, Welschmeyer \& Lorenzen 1984)

\section{DISCUSSION}

Because the 2 methods for measuring phytoplankton growth rate agreed well, we conclude that the traditional approach of estimating $\mu_{1}$ from productivity:biomass is reasonable. Results of these experiments further demonstrate that estuarine phytoplankton populations have the potential to increase biomass very quickly (i.e. 2 divisions $\mathrm{d}^{-1}$ ) where the photic depth is large relative to the mixed depth. Conversely, we found small or negative growth rates in the turbid channel of the North Bay where $Z_{p}: Z_{m}$ is small. These results support our hypotheses that phytoplankton growth rates can be highly variable spatially, rapid in clear shallow waters (e.g. South Bay shoals) and extremely slow in turbid deep waters (e.g. North Bay channel).

Among others, Cole \& Cloern (1987) have shown that phytoplankton productivity is controlled largely by light availability in a wide range of estuarine environments. An objective of this study was to test the hypothesis that variations in phytoplankton growth rate are similarly controlled largely by variations in light availability. Our results demonstrate a quantitative relationship between growth rate and light exposure. Over a range of light exposure frequencies (Fig. 3), measured growth rates increased with total daily light exposure and fit a hyperbolic function (Fig. 5) that predicts a maximum specific growth rate of about 2 divisions $\mathrm{d}^{-1}$ as daily irradiance $I$ approaches 10 Einst. $\mathrm{m}^{-2} \mathrm{~d}^{-1}$. A similar hyperbolic relation between growth and irradiance has been observed by Langdon (1987), who measured both particulate organic carbon increase and cell division rate in cultures. Our results also follow the pattern demonstrated by many others (e.g. Bannister 1974, Platt \& Jassby 1976, Malone \& Neale 1981, Peterson et al. 1987) for the relation between photosynthesis and irradiance. This function also predicts zero growth rate when $I<1.4$ Einst. $\mathrm{m}^{-2}$ $\mathrm{d}^{-1}$. Hobson \& Guest (1983) have reported daily compensation irradiance $\left(I_{\text {comp }}\right)$ values between 0.08 and 1.9 Einst $\mathrm{m}^{-2} \mathrm{~d}^{-1}$ for neritic phytoplankton. Our results are also within the range $\left(0.06\right.$ to 1.76 Einst. $\left.\mathrm{m}^{-2} \mathrm{~d}^{-1}\right)$ that Langdon (1987) found in a laboratory study of 3 phytoplankton species: a diatom, a chrysophyte and a dinoflagellate.

Given the protocol of experiments described here, we conclude that an apparent minimum irradiance of about 1.4 Einst. $\mathrm{m}^{-2} \mathrm{~d}^{-1}$ is required to sustain phytoplankton population growth in San Francisco Bay. By knowing this minimum irradiance value (i.e. $I_{\text {comp }}=1.4$ Einst. $\mathrm{m}^{-2} \mathrm{~d}^{-1}$ ) and substituting it for $I$ in Eq. (5), which gives the mean irradiance in a totally absorbing water column, we can estimate tho critical $Z_{p}: Z_{m}$ ratio needed to sustain growth:

$$
I=\left(I_{0} \times Z_{\mathrm{p}}: Z_{\mathrm{m}}\right) / 4.61
$$

For an average summer day (surface irradiance $I_{0}=40$ Einst. $\mathrm{m}^{-2} \mathrm{~d}^{-1}$ ) we calculate that the critical $Z_{\mathrm{p}}: Z_{\mathrm{m}}=$ 0.16 , which is consistent with the critical $Z_{\mathrm{p}}: Z_{\mathrm{m}}$ ratio for photosynthesis (Cloern 1987). This implies that when

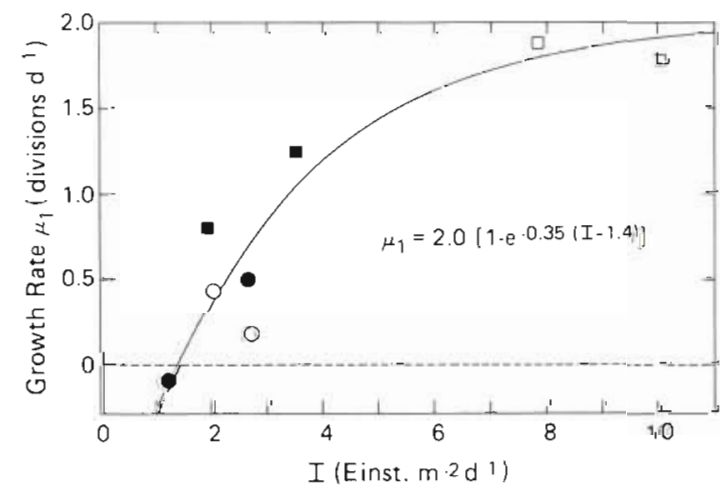

Fig. 5. Phytoplankton growth rate as a function of irradiance during simulated vertical mixing. Measurements were made at 4 sites (see Fig. 1) during September 1984 using 2 vertical mixing rates per site 
the photic depth is less than approximately $16 \%$ of the mixed depth, phytoplankton growth cannot be sustained.

Our results demonstrate that phytoplankton population dynamics can be strongly influenced by the ratio $Z_{\mathrm{p}}: Z_{\mathrm{m}}$ in estuaries, as in lakes (e.g. Harris et al. 1980, Horn \& Paul 1984, Grobbelar 1985). We can measure $Z_{\mathrm{p}}$ accurately but do not yet have an equivalent capability to quantify the mixed depth $Z_{\mathrm{m}}$ particularly when density gradients are present in the water column. Even if $Z_{\mathrm{m}}$ is well defined, it remains difficult to use physical properties (e.g. vertical density or velocity gradients) to infer trajectories of movement, and therefore mean light exposure, of phytoplankton populations. Experimental results such as those presented here emphasize the need for collaborations between phytoplankton ecologists and physical scientists to better characterize the vertical motions of phytoplankton, and thus enhance the utility of empirical functions (e.g. Fig. 5) to estimate phytoplankton growth rates in nature.

Acknowledgements. We gratefully acknowledge Ray Wong, Brian Cole and the crew of the RV 'Polaris' who assisted in this study. We thank J. Thompson and T. Hollibaugh for manuscript reviews.

\section{LITERATURE CITED}

Bannister, T. T (1974). A general theory of steady state phytoplankton growth in a nutrient saturated mixed layer. Limnol. Oceanogr. 19: 13-30

Cloern, J. E., Cole, B. E., Wong, R. L. J., Alpine, A. A. (1985). Temporal dynamics of estuarine phytoplankton: a case study of San Francisco Bay. Hydrobiol. 129: 153-176

Cloern, J. E. (1987). Turbidity as a control on phytoplankton biomass and productivity in estuaries. Cont. Shelf Res. 7: $1367-1381$

Cole, B. E., Cloern, J. E. (1987). An empirical model for estimating phytoplankton productivity in estuaries. Mar Ecol. Prog. Ser. 36: 299-305

Cosper, E. (1982). Influences of light intensity on diel variations in rates of growth, respiration and organic release of a marine diatom: comparison of diumally constant and fluctuating light. J. Plankton Res. 4: 705-724

Cullen, J. J. (1982), The deep chlorophyll maximum: comparing vertical profiles of chlorophyll a. Can. J. Fish. aquat. Sci. 39: 791-803

Denman, K. L., Gargett, A. E. (1983). Time and space scales of vertical mixing and advection of phytoplankton in the upper ocean. Limnol. Oceanogr 28: 801-815

Furnas, M. J. (1982). Growth rates of summer nanoplankton $(<10 \mu \mathrm{m})$ populations in lower Narragansett Bay, Rhode Island, USA. Mar Biol. 70: 105-115

Gallegos, C. L., Platt, T (1982). Phytoplankton production and water motion in surface mixed layers. Deep Sea Res. 29: $65-76$

Grobbelaar, J. U. (1985). Phytoplankton productivity in turbid waters. J. Plankton Res. 7: 653-663

Haffner, G. D., Harris, G. P., Jarai, M. K. (1980). Physical variability and phytoplankton communities. III. Vertical structure in phytoplankton populations. Arch. Hydrobiol. 89: $363-381$

Harding, L. W., Meeson, B. W., Fisher, T R. (1986). Phytoplankton production in two east coast estuaries: photosynthesis-light functions and patterns of carbon assimilation in Chesapeake and Delaware Bays. Estuar. coast. Shelf Sci. 23: 773-806

Harris, G. P., Haffner, G. D., Piccinin, B. B. (1980). Physical variability and phytoplankton communities. II. Primary productivity by phytoplankton in a physically variable environment. Arch. Hydrobiol. 88: 393-425

Harris, G. P., Piccinin, B. B. (1980). Physical variability and phytoplankton communities. IV. Temporal changes in the phytoplankton community of a physically variable lake. Arch. Hydrobiol. 89: 447-473

Hobson, L. A., Guest, K. P. (1983). Values of net compensation irradiation and their dependence on photosynthetic efficiency and respiration in marine unicellular algae. Mar. Biol. 74: 1-7

Horn, H., Paul, L. (1984). Interactions between light situation, depth of mixing and phytoplankton growth during the spring period of full circulation. Int. Revue ges. Hydrobiol. 69: $507-519$

Jewson, D. H., Wood, R. B. (1975). Some effects on integral photosynthesis of artificial circulation of phytoplankton through light gradients. Verh. int. Verein. Limnol. 19; $1037-1044$

Langdon, C. (1987). On the causes of interspecific differences in the growth-irradiance relationship for phytoplankton. Part I. A comparative study of the growth-irradiance relationship of three marine phytoplankton species: Skeletonema costatum, Olisthodiscus luteus and Gonyaulax tamarensis. J. Plankton Res. 9: 459-482

Lewis, M. R., Horne, E. P. W., Cullen, J. J., Oakey, N. S., Platt, $T$ (1984). Turbulent motions may control phytoplankton photosynthesis in the upper ocean. Nature, Lond. 311: $49-50$

Lorenzen, C. J. (1967). Determination of chlorophyll and pheo-pigments: spectrophotometric equations. Limnol. Oceanogr. 12: 343-346

Malone, T. C. (1977). Environmental regulation of phytoplankton productivity in the Lower Hudson Estuary. Estuar. Coast. Mar. Sci. 5: 151-171

Malone, T. C., Neale, P. J. (1981). Parameters of light-dependent photosynthesis for phytoplankton size fractions in temperate estuarine and coastal environments. Mar. Biol. 61: $289-297$

Marra, J. (1978). Phytoplankton photosynthetic response to vertical movement in a mixed layer. Mar. Biol. 46: 203-208

Parsons, T. R., Takahashi, M., Hargrave, B. (1977). Biological oceanographic processes, 2nd edn. Pergamon Press, Oxford

Peterson, D. H., Perry, M. J., Bencala, K. E., Talbot, M. C. (1987). Phytoplankton productivity in relation to light intensity: a simple equation. Estuar coast. Shelf Sci. 24: $813-832$

Platt, T., Jassby, A. D. (1976). The relationship between photosynthesis and light for natura]. assemblages of coastal marine phytoplankton. J. Phycol. 12: 421-430

Pruder, G. D., Bolton, E. T (1980). Difference between cell division and carbon fixation rates associated with light intensity and oxygen concentration: implications in the cultivation of an estuarine diatom. Mar. Biol. 59: 1-6

Reynolds, C. S., Harris, G. P., Gouldney, D. N. (1985). Comparison of carbon-specific growth rates and rates of cellular increase of phytoplankton in large limnetic enclosures. J. Plankton Res. 7. 791-820 
Riemann, B. (1978). Carotenoid interference in the spectrophotometric determination of chlorophyll degradation products from natural populations of phytoplankton. Limnol. Oceanogr. 23: 1059-1066

Schindler, D. W., Schmidt, R. V., Reid, R. A. (1972). Acidification and bubbling as an alternative to filtration in determining phytoplankton production by the ${ }^{14} \mathrm{C}$ method. $\mathrm{J}$. Fish. Res. Bd Can. 29: 1627-1631

Walters, R. A., Cheng, R. T., Conomos, T J. (1985). Time scales of circulation and mixing processes of San Francisco Bay waters. Hydrobiologia 129: 13-36

Welschmeyer, N. A., Lorenzen, C. J. (1984). Carbon-14 labeling of phytoplankton carbon and chlorophyll a carbon: determination of specific growth rates. Limnol. Oceanogr. 29: 135-145

Wienke, S. M., Cloern, J. E. (1987). The phytoplankton component of seston in San Francisco Bay. Neth. J. Sea Res. 21. 25-33

Wong, R. L. J., Cloern, J. E. (1982). Plankton studies in San Francisco Bay. IV. Phytoplankton abundance and species composition. January 1980-February 1981 U.S. Geol. Survey Open-File Report 82-443: 1-152

Yoder, J. A., Bishop, S. S. (1985). Effects of mixing-induced irradiance fluctuations on photosynthesis of natural assemblages of coastal phytoplankton. Mar. Biol. 90: $87-93$

This article was submitted to the editor; it was accepted for printing on March 4, 1988 